of resistant Staphylococci from pigs and chickens and from their attendants ; most of these organisms were resistant to 'nutritional levels' of the antibiotics fed to the animals and would be expected still to be sensitive to therapeutic dosage-levels. More recently Williams Smith (Res. Vet. Sci., 1, 182; 1960) has shown that the widespread use of antibiotics in pig feeding in Britain has had no pronounced effect in increasing the number of resistant Salmonellae in the general pig population. This is highly significant (or insignificant?) epidemiologically, and is of particular interest in contrast with the observations of Garside, Gordon and Tucker (Res. Vet. Sci., 1, 184 ; 1960) on experimental Salmonella typhimurium infection in chickens, concerning the possible effects of 'nutritionally induced' antibiotic resistance on the Salmonella carricr state. However, high levels of antibiotic feed supplementation were used for prolonged periods in some of their experiments, exaggerating the degree and persistence of the bacterial antibiotic resistance thus induced. Moreover, there was no evidence of any relationship between resistance, pathogenicity and virulence; it is thus important that, should problems exist, they would not relate to unduly malignant organisms of enhanced potency.

\section{The High Polymer Research Group}

The High Polymer Research Group has been founded under the chairmanship of Sir Harry Molville, for the purpose of organizing study conferences. The first conference, which will be held during April 17-20, 1961, will consider the relationship between chemical structure and physical properties of clastomers. The policy of the Group is to encourage the free exchange of ideas between active workers from all countries in the chosen field, and for that reason participation will be by invitation only. The proceedings of the Group will not be recorded, nor will papers which are read before the Group be available for publication. The offices of the Group are at 14 Belgrave Square, London, S.W.1.

\section{Historic Books on Mining and Kindred Subjects}

Recentuy the Science Museum, South Kensington, has staged No. 4 of its occasional exhibits of historic books on scientific and technological subjects. This new exhibition is of works on metalliferous mining, metallurgy, mining machinery, mining laws and customs, mineralogy, precious stonos and rolated subjects (see Nature, 188, 538; 1960). The books themselves have been generously lent to the Musoum by Mr. Robert Annan, a mining engineer, from his private collection. Many are illustrated, and nearly all are of considerable rarity. Mining is perhaps the oldest of human industries, extending back into prehistoric times, when flints were mined to make implements. Records of early mining activities before the commencement of printing are naturally very scarce, but the exhibit contains a reproduction of the illustrated title page of a fifteenth century manuscript, the "Kuttenborger Kanzionale". This is primarily a treasury of old mining songs, but contains illustrations that form a valuablo record of the life and activities of a mining community of the period. The printed books cover the period from the late fifteonth to the early nineteonth century. Opportunities for the public to examine such a cornprehensive collection of classic mining works occur very seldom indeed, and this exhibit should not be missed by those interested. The exhibition will remain opon until December 31. An annotated catalogue has been issued, which can be obtained from the Museum, or from H.M. Stationery Office (Book Exhibitions, No. 4: Historic Books on Mining and Kindred Subjects. Pp. 32. 1s. 6d.).

\section{Theoretical Atomic Physics in Norway}

DURING the period covered by its second annual report (1958-59), the Nordisk Organization for Teoretisk Atomfysik was still operating on an interim basis, since the adoption of the convention on which its activities are to be based formally has had to be postponed (Pp. 46. Copenhagen : Nordisk Organization for Teoretisk Atomfysik, 1960). The temporary board, consisting of four members each from Denmark and Norway, three from Finland and Sweden, and one from Iceland, with Prof. Niels Bohr as chairman, held two meetings during the year. The staff on Juno 30, 1959, consisted of Prof. C. Moller as director and three scientific and three administrative staff. There were eleven Research Fellows As in the previous year, courses of lectures and colloquia were held regularly, and detailed lists of those together with the papers published by members of Nordita are given in the report. Offprints of the papers appear as numbers in a series entitled "Nordita Publications", and are sent on request without charge to institutions and scientists interested in them. Notes of some of the lecture courses have also been issued and are similarly available.

\section{Ergonomics and Automation}

THE Department of Scientific and Industrial Research has sponsored a study of the human implications of automation. This was carriod out under the direction of A. T. Welford and included a critical appraisal by Miss H. M. Clay and Mr. Welford of recent research, as well as a survey of existing practice in industry by E. R. F. W. Crossman. Two publications have now been issued in the series "I'roblems of Progress in Industry", describing these investigations. The first, "Ergonomics of Automation", describes research relevant to the problems of the human operator in an automatic plant, with special emphasis on the design of equipment (Problems of Progress in Industry, No. 8. Pp. 60. London: H.M. Stationery Office, 1960. 3s. 6d.). The second, "Automation and Skill", gives an account of the industrial survey, and discusses the skills required of human operators in highly mechanized and automatic plants, as well as problems of selection and training (No. 9. By E. R. F. W. Crossman. Pp. 59. London: H.M. Stationery Office, 1960. 3s. 6d.).

\section{The National Museum, Bloemfontein}

The annual report of this Museum for the year ended March 31, 1960, forms encouraging reading as it records the near-completion of two new wings (Pp. 22. Bloemfontein: National Museum, 1960). This increased accommodation will give four exhibition halls and twelve extra workrooms for the staff. The latter provision will give much better facilities for research. A cafotoria has also been included. The building programme interfered with the normal activities of the Museum, and research and field work almost ceased. It has also entailed the withdrawal of the usual facilities to senior university students in anthropology and history. In spite of these additions to the buildings, exhibits illustrating the proto-bushman and fossil reptile-tracks have been preparod. 